\title{
Kuinka tässä nyt taas näin kävi?
}

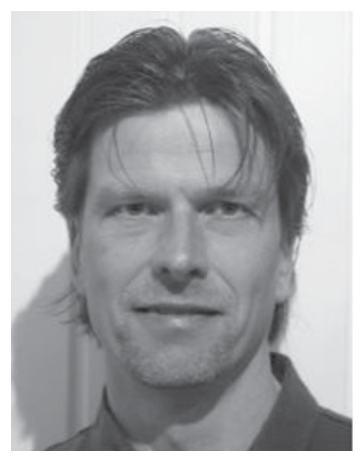

$V_{i}$ ietämme Euroopan unionissa luovuuden ja innovoinnin teemavuotta. Oletan, että moni aikuiskasvattaja toivoi reilun vuosikymmenen takaisen elinikäisen oppimisen teemavuoden saattavan suuren yleisön (ja päättäjien) tietoisuuten sen, että toimimme ja opimme arjen monimuotoisissa viitekehyksissä. Toisin kuitenkin kävi. Yhtenä esimerkkinä toimikoon erilaiset välineet ja järjestelmät opitun tunnistamiseksi ja tunnustamiseksi (validation). Arkipäiväistä, spontaania, hiljaiseksi kokemukseksi muotoutuvaa oppimista arvostetaan vasta kun se on mitattu, tunnistettu ja muodollistettu.

Opitun tunnustaminen, kompetenssit ja kvalifikaatiot sekä aikuiskouluttajan toiminnan laatu olivat vahvasti esillä niissä esityksissä, joihin osallistuin noin kuukausi sitten Tanskassa pidetyssä Pohjoismaisessa aikuiskasvatuskonferenssissa. Osassa esityksistä käsiteltiin inspiraatiota, luovuutta, estetiikkaa ja innovaatiota. Mutta kovin jälkitayloristisessa ja pragmaattisissa viitekehyksessä. Luovuus ja esteettisyys näyttäytyivät joko päälleliimattuna designina tai "uutena” käyttöönotettavana voimavarana.

erinteisesti luovuus voitaneen ymmärtää valmiutena tunnistaa epäjohdonmukaisuuksia, ennalta arvaamattomia asiayhteyksiä ja tutusta poikkeavuuksia sekä kykynä nähdä, tehdä ja toimia toisin. Luova hulluus merkitsee olemassa olevien käytäntöjen ja sovinnaisuuden kyseenalaistamista - irtiottoa vanhasta. Rooman klubille vuonna 1979 julkaistussa kirjasessa No limits to learning bridging the human gap todetaan muun muassa seuraavaa: "Yhteiskunnissa on tapana odottaa kriisiä ennen kuin niissä ryhdytään kannustamaan ja edistämään innovaatiivissta oppimista” sekä "Innovatiivisen oppimisen suurimmat esteet liittyvät jäykkiin rakenteisiin sekä vallan väärinkäyttöön.” Varteenotettavia huomioita ja oikeaan osuneita ennusteita.

Ensimmäisen sukupolven yhteiskunnalliset liikkeet olivat aikoinaan sosiaalisia ja yhteiskunnallisia innovaatioita, joiden avulla kyettiin purkamaan ja uudistamaan vanhoja valtarakenteita, luomaan uudenlainen sosiaalinen järjestys. Niiden tavoitteet ja toimintamuodot tiivistyivät Pohjoismaisen aikuiskasvatuskonferenssin otsikossa kolmeen käsitteeseen "Vuorovaikutus, yhteistyö ja luovuus”. Tämän päivän kolmannen sektorin sosiaaliset innovaatiot tunnistetaan mittaamalla niiden lisä-arvoa, tulosta ja tuottavuutta. Samalla poissuljetaan ja hävitetään se dynamiikka, liike ja aktivismi, joka synnyttää uutta ja erilaista. Tarvitsisimme kipeästi uus-vapauttavaa aikuiskasvatusta (neo-liberating adult education).

altioneuvoston tuoreessa innovaatiopoliittisessa selonteossa eduskunnalla innovaatio määritellään "osaamislähtöiseksi hyödynnetyksi kilpailueduksi”. 
Tukkimiehen kirjanpitokäytäntöön perustuva pseudosemanttinen analyysi tuottaa seuraavanlaisen tuloksen: Innovaatio = osaaminen + lähtö, hyöty, kilpailu, etu. Tähän teknokraattiseen ja ekonomistiseen määritelmään ovat reagoineet muutkin kuin minä. Sibelius-Akatemian kansanmusiikin professori Hannu Saha tarjosi hiljan radiopakinassaan sen vastapainoksi arjen ahertamiseen sisältyvää "luonnollista” luovuutta sekä kiinnitti huomiota arkielämän esteettisiin valintoihin. Innovaatioasiamiehen rinnalle hän talutti kouluttamattoman liiteri-picasson.

$\mathrm{M}$ ikä on tieteen luovuuspotentiaali? Kykeneekö se edes elämään omassa ajassaan? Siinä missä yhteiskuntatieteilijä on juuri ennättänyt lähettää tutkimussuunnitelmansa potentiaalisella rahoittajalle, on taiteilija, oli hän sitten tanssija, dramaturgi tai rocktyöläinen ensiesittänyt uuden, työelämän tai yhteiskunnan tilaa kommentoivan teoksensa. Kokemuksellisuuden lisäksi taide koskettaa - sekä yksilöä että yhteisöä. Suomalaista identiteettipääomaa kommentoiva ja haastava teatteriesitys tai nukkeanimaatio synnyttää vahvoja reaktioita. Sitä arvioidaan vahvan tunnekuohun vallassa, joskus ilman omakohtaista kokemusta keskustelun kohteena olevasta teoksesta. Ihmis- tai yhteiskuntatieteelliset tutkimustulokset saavat vastaavanlaista huomiota ainoastaan käsitellessään aiheita, jotka herättävät tunteita - inhoa, pelko, vihaa. En peräänkuuluta tutkimukselta tietoista mediaseksikkyyden perässä juoksemista. Kyse on pikemminkin yhteiskunnallisesta vaikuttavuudesta. Kyse on siitä, että kymmenien miljoonien akatemiaprojektien tulokset saataisiin kansalaisten ja heidän edustajiensa tietoisuuteen, kahvipöytä- tai tupakkatuokiokeskustelujen aiheiksi - herättämään tunteita. Tulisiko tieteilijän (avo)liittoutua taiteilijan kanssa? Voisiko aikuiskasvatustieteen tutkimustuloksia esitellä ja käsitellä yhteisöteatterissa?

apaa sivistystyö on kautta aikain ollut monipuolinen luovuuslaboratorio, jossa on kyetty monenmoisiin rajanylityksiin. On kuitenkin paradoksaalista, että juuri taito-ja taideaineet ovat asialistalla lähes aina, kun vapaan sivistystyön organisaatioiden toimintaa halutaan kyseenalaistaa. Vapaan sivistystyön kehittämisohjelmassa taide mainitaan peräti kaksi kertaa, luovuus ja innovaatio kumpikin kerran. Kaivan lopuksi naftaliinista aina yhtä mukavalta maistuvan sivistävien huvien käsitteen. Zen Cafen Aamuisin, Kristian Smedsin Tuntematon sotilas ja Katarina Lillqvistin Uralin perhonen ovat sivistäviä huveja. Niissä tiedetään taitaen.

\section{Petri Salo \\ psalo@abo.fi}

